\title{
The Inheritance and Variation of Confucian Family Culture - Concept of Family Household and Group Consciousness in Japanese Social Culture
}

\author{
Ying Zhang \\ School of Foreign Studies, Xi'an University, 710065
}

Keywords: Confucian; Family culture; Inheritance; Variation

\begin{abstract}
Family is the basic unit of society, and is a small unit of society. Parents are the core of the family, and family members are the organizational part of the family. This is the basic concept of the ancient family and is also the core of home culture of Confucianism. The optimization and variation had been generated after the concept of the family was learned by the Japanese. In the development plan of family household concept and group consciousness of Japanese society, essentially, the Japanese group consciousness comes from the concept of the traditional family on Japanese, and this idea of family is to inherit the parent-child relationship of the Chinese Confucian culture. This paper aims to explore the promotion and deduction of Confucian family culture on group consciousness in Japanese social culture.
\end{abstract}

\section{Introduction}

Confucianism believes that the family is smallest production unit after the formation of clan society, and is also the conceptual foundation of close interest connection with the actual social relations. Generally, the main body of family includes husband and wife, parents and children. The real concept of family consolidation for children is after the marriage. People multiply the next generation, which comes into being another production unit from the family. Price control is actually the will of the parents; parents are responsible for the family, and it is a democratic and harmonious relationship among the families. Confucianism, the concept of thousands of years of feudal society and the close relationship of the family was used by the Japanese to the collective characteristics of the Japanese people, which makes a very important impact in the Japanese growth and the development process of Japanese national enterprise.

\section{Development Background of Inheritance Culture of Japanese Family Household}

East Asian countries belong to the cultural circle of Han nationality in Asia, and they have been influenced by the Chinese Confucianism since ancient times. Japan's absorption of Chinese Confucianism is particularly profound. Japan's history of development has always been guided by Confucianism upon which this country replies. The important content of Chinese Confucianism is that the family has close blood ties, and the family must have a mainstay to take the responsibility for a decision, that is, parents. Confucianism is an important concept which expects to achieve social stability for self-cultivating, family-regulating, state-ordering and the land great governed. It hopes that people can first love their own family members, love the populace extensively and be close to those who are humane. In this family, everyone will maintain the interests of their own family and do their best to maintain their own family's reputation. This idea has been the important viewpoint for Japanese family and business to inherit for a long time and has been actively performed. Based on the interaction concept of the development of Confucian family culture to Japanese social culture, Japanese attach great importance to the continuation of the blood lineage. Like the traditional Chinese people, Japanese pay much attention to continuation of lineage. If there is a prestigious person in one Japanese family, he will become the pride of the entire Japanese ethnic groups.

Japanese traditional moral norms and kinship is based on the law and the affection of the inseparable family; in order to complete the family's common interests, on the basis of acceptance and reference of traditional Chinese culture, Japanese developed the family household concept 
which has continued to the modern day. But based on the absorption and imitation of Chinese culture, Japanese also develop and innovate Japanese culture on the basis of learning with China. Japanese culture pays more attention to the family's economic community awareness, that is, on the basis of pedigree of the family household economy community and concept of inheritance of which parents take the responsibility for a decision, the interest combinations of parent-child relationship and economic community are more profound and close for Japanese. Learning from Confucianism, it is not necessary for the close blood relationship, for example, the live-in son-in-law can also be treated as a parent-child after changing the surname, which can make an independent economic community a better continuation. This is to maintain the family economic and prestige interests that Japanese make sacrifices and adjustments in the combined economic development process. This is also an adaptation for a family to make the common interest get along well. The Japanese etiquette education has long been a courteous education. The identification of blood relationship for Japanese is not the most important. It is more important to the family interests of which they actually live together on the basis of joint efforts of exchange of needed goods, cross subsidization, hardworking and conscious constraints for the family economic interests. In other words, in order to preserve the integrity of the independency and economic community, Japanese can adjust the blood lineage and inheritance.

\section{The connotation of the Concept of Family Household in Japan and its Influence}

Profoundly Influenced by Chinese Traditional Confucianism. The concept of the Japanese family household is absolutely influenced by traditional Chinese Confucianism. Confucian traditional thought is respecting for teachers and stresses parent restraint, and everyone should be diligent and live together restrained by moral code. The traditional Confucianism and Confucian culture of Chinese family advocates theory of blood relation, utilitarianism, cultivation of the morality and the mind, and moral ration, and its central idea is forgiveness, loyalty, filial piety, respect of brothers, brave, benevolence, righteousness, ritual, wisdom, and faith, of which benevolence is the core. Confucianism has been highly praised by successive governors, and has been developed and inherited by Confucianism and the following theories, which has played a decisive role in the development of Chinese culture. In the deep view of Chinese culture, the Confucianism has been branded. From the present concept of family household and group consciousness in Japan, we can see that all aspects are profoundly with the shadow of Chinese traditional Confucianism. Under the influence and drive of Confucianism, the shadow of the concept of Japanese family household is based on the common harmonious order and psychological balance of social practice. It provides a kind of relative concentration of family power for the present economic development, possessing an absolute authority of right of dominion to veritably act as the head of the family under the name of the householder. This authority can guarantee the economic base of Japan and the economic status of the members of the family, so the head of the Japanese family may become the actual head of the family after his son growing into an adult. The family status is decided by the economic status and the degree of property possession, which is a more realistic concept of the family household; in a sense, it is also a more advanced concept of the family, but has Japanese traditional cultural cruelty as well.

\section{Confucianism and Family Household Culture Attached Importance to Family and Family Ethics}

However, like Confucianism, the Japanese interactive culture pays much attention to the vertical blood relation. As the family's continuation and the basic unit of family survival, if you are very concerned about the family harmony, you will be fair and equitable as much as possible for the inheritance of property. People should support the family pedigree as much as possible, especially in the process of economic assistance and common progress, after the signature is given, the two sides will perform their duties. The concept of procedural thinking designed by ancestors should be 
followed strictly whether it is for superior or subordinate. This idea is actually the embryonic form of collectivism. This concept, which is influenced by the Confucianism, is the concept of the family of the Japanese community to help with each other and convey the idea of living community. In fact, it is the ubiquitous concept of the family in the Japanese society that is in an early form of the Japanese potential group consciousness idea. Japanese society anthropologist highly praises a special type of the common life business with the family as the prototype, which is a profound integration of Confucianism with the couple and their children constituted the smallest unit that is the social group unit with the group or complex of blood ties as the link. Confucianism pays attention to the concept of family in the economic entity, which is performed vividly in Wenzhou, China. This is relatively coincident with the concept of the Japanese family household, which promotes the rapid development of the local economy.

\section{Emphasizing the Continuity of a Clan and Blood Lineage of Confucian Culture}

Confucian culture attaches great emphasis on the relationship of continuity of a clan and blood lineage. The concept of the Japanese family household also attaches great importance for this vertical relationship. Japan still retains the Tennoism, and some large enterprises in Japan also emphasize on the direct successor's blood relationship. But Japanese regard the continuation of the patrilineal line and the continuation of the maternal blood as an important thing; and enrolled in the Japanese family through the son-in-law or daughter-in-law, the surname will be changed if they agree. Japanese family also pays much attention to the new persons enrolled in the family, and the simulated blood relationship is also very strong. In fact, in the Japanese family consortium or the Japanese economic entity, the community of living of the simulated blood relationship and the group consortium also makes a very positive effort and contribution in order to promote the prosperity of the transaction. This is different in China. Chinese people think that their body flow the blood of the ancestors, and family blood relationship is prior to other social relations; while in Japan, simulated blood relationship can also be well accepted.

\section{The Concept of Equalization and Average Maintenance of Japanese Property}

Japan is a very egalitarian society and an economically developed society. Japanese people have the distinguishing concept of property management as well. This concept of equal maintenance and average distribution of property is consistent with the idea of fairness of Chinese Confucianism. In Japan, the law will respect the individual's equality and dignity of the choice of divorce, marriage and family affairs, and the Japanese take the basis of gender substantive equality very seriously. The civil law specially regulates the family law and birth. It is worth mentioning that the women's rights in the legal guarantee, all being positive, if a woman reproduces at home, generally she will decide to take children at home and take care of the family, and her husband will enjoy the corresponding subsidies, of which amount is considerable. For Japanese women and men, the divorce is more secure for women's economic interests, which reflects the fairness. And in the process of Japanese family relationship survival, Japan's maintenance concept and the concept of the average distribution of property is also more equal. Generally, the Japanese family members will strictly follow the idea of equality, which will not change a lot due to how much they pay out or the emotional distance. Although there is also the gift of behavior, it will not have a decisive influence, thus providing a relatively fair environment for the concept of family household in Japanese society. Japanese people have potentially formed an average distribution consciousness in economic entity, which is deep-rooted.

\section{Concept of Japan's Family Household in the Post-War Development Process}

Effect of Concept of Family Household on Modern Economic Development. The concept of the family household in Japanese social culture has a very far-reaching impact on the development of modern economy. The concept of the family household played an important basic role for the 
development of Japanese Group mind in Japanese social enterprise culture. Japan has undergone a postwar reconstruction, but it has been used in just a few decades to achieve the economic, political, social and cultural changes and prosperity. In this process, it is Japanese conglomerates that hold important missions. The management practices adopted by Japanese conglomerates are based on the Japanese traditional group consciousness. And the reason why the Japanese can be so united, in fact, is because of the idea of family, which is a more inclusive concept of scientific family household, and is an advanced concept without blood discrimination. This advanced concept produced Japanese group thought; Japan-made products were full of the country, which promoted the economic development. It can be said that the Japanese were wrapped at the group of family from the moment of birth, and the group interests of the family request the individuals to obey the group. In the process of the development of traditional culture of tolerance for each person, the decline of family group is the cause of personal decline, and the community makes the Japanese society quite united. Japanese have shown a very great combat effectiveness in the process of military economic construction, which also reflects the spirit of sacrifice.

\section{The Modern Japanese Group Consciousness and the Deep- Rooted Concept of Family Household}

In the modern Japanese group consciousness, the deep-rooted concept of the family household is actually developed in the traditional historical and cultural backgrounds under the influence of Confucianism. From the historical point of view, the Japanese group consciousness has a close relationship with its village culture of the agricultural society. Village "mura" and is related to group "mure", and the group behavior of the village is the historical and cultural background of the formation of the Japanese group consciousness. In the medieval agricultural production, individual villagers could only rely on the collective to cope with natural disasters, heavy land rents and emergencies. A village is a production community; getting out of the community means the end. Japanese village has a tradition village eight. The so-called "village eight" refers to ten kinds of intercourses and eight sanctions. Ten kinds of intercourses include giving birth to a child, adult ceremony, marriage, visiting the patient, funeral, religious rites, fire, flood, travel, Puqing (building). If a villager meets one of ten cases, he will be helped by the whole village; but once someone is unworthy, he and his family will be broken off the eight of the ten intercourses except for fires and funerals, which will make it difficult for individuals and their families to survive. This tradition penetrates into different levels of society in different ways, making the Japanese rely on groups and fear of loneliness, and have a strong dependent psychology and wish, which are the important factors for the emergence and development of group consciousness. This Japanese group consciousness is deep-rooted, with the concept of family and group over everything else.

\section{Loyalty Concept and Loving Society like Family Respected by Regular Recruitment System}

Japanese people have a lot of technical talents, and Japanese companies require that the individual is absolutely loyal to the enterprise. In Japan, whether the highly noble management talents or the technical personnel with professional skills, they are asked to love society like family at the moment they join the enterprise. Japanese companies are much respected for the Japanese professional quality and loyalty; even if the technology or level is first-class, if the ideological methods and moral qualities do not meet the company's requirements, the company will not hesitate to dismiss the employees who are believed to be unqualified. Japan's recruitment and recruitment system is regularly launched, and the competition is very intense. Japanese companies are even very inclined to recruit new graduates as they believe that the new school graduates are just like white paper and can be used loyally by companies after accepting the strict normative training. It is in the admiration of this idea that Japanese are often very dedicated. Japan's family concept is combined well in the infiltration of group consciousness and the process of development, making the group interests very consistent, with the group of condensation being a strong fist force. 


\section{Conclusions}

We can find the development of family household concept in Japanese social culture from the heredity and variation of the Confucian family cultural thoughts. As the basic link, this creative use of ideas is the rise of the nation of which the concept of group consciousness can be more expanded with cohesion and explosive force. In this idea, the developed group consciousness of Japanese has great combat effectiveness under the influence of loyalty and the influence of the exclusion of nationalism tendencies.

\section{Reference}

[1] S.L. Wei: The idea of basic administration in Chinese traditional culture and its enlightenment to the realization of "China Dream" - A case study of Taoism, Confucianism and Legalists. Education and Teaching Forum, Vol. 34 (2016), p. 55. (In Chinese)

[2] N.B. Qin: A study of the Confucian cultural view of the Communist Party of China in the period of Democratic Revolution (Shandong Normal University, China 2016). (In Chinese)

[3] W.B. Tian: Confucian culture and hundred schools of thought: The origin of Wushu 's development. Fighting (Wushu Science), Vol. 03 (2015), p. 2. (In Chinese)

[4] T. Cao: Clan imagination, cultural gene and settlement landscape form (Central South University of Forestry and Technology, China 2014). (In Chinese)

[5] Y.Y. Wang: The application of Confucian legalists and Taoist thinking in the Construction of enterprise culture. Oriental Corporate Culture, Vol. 20 (2013), p. 263. (In Chinese)

[6] Q. Fan: An analysis of the influence of Chinese traditional political culture on political legitimacy - A case study of Confucian and legalists' political thoughts. Social Science and Technology (New Theoretical Edition), Vol. 03 (2010), p. 183. (In Chinese)

[7] H.F. Yang: Inheritance and variation: an analysis of the dissemination dimension of Confucian cultural gene inheritance. Journal of Ningbo Radio \& TV University, Vol. 03 (2009), p. 118. (In Chinese)

[8] D.G. Yang: The inheritance of Confucian benevolence idea in the establishment of family cultural system in modern enterprises. Management Bbservation, Vol. 13 (2009), p. 218. (In Chinese)

[9] Z.R. Yang: The embodiment of Confucian culture and multi-structure culture in "family" Comparison between The Family of Ba Jin and The Family of Tōson Shimazaki. Journal of Tonghua Teachers College, Vol. 03 (2008), p. 69. (In Chinese)

[10] J.P. Huang: A comparison between Confucianism in The Tales of the Heike and Romance of the Three Kingdoms (Chongqing Normal University, China 2006). (In Chinese)

[11]J.W. Fan: The modern value of Confucian educational thoughts and their moral education tradition from the conflict and fusion of modern education (Xi'an Technology University, China 2003). (In Chinese)

[12]X. Xiao: The inheritance and variation of Confucian family culture - Family household and group consciousness in Japanese social culture. Journal of Theoretical Studies, Vol. 03 (2002), p. 114. (In Chinese) 